\title{
R\&D Direction and North-South Diffusion, Human Capital, Growth, and Wages
}

\author{
Óscar Afonso \\ Faculdade de Economia, Universidade do Porto and CEFUP, Rua Roberto Frias, 4200-464 Porto, Portugal \\ Correspondence should be addressed to Óscar Afonso, oafonso@fep.up.pt
}

Received 18 January 2011; Revised 11 April 2011; Accepted 5 May 2011

Academic Editor: Almas Heshmati

Copyright ( 2011 Óscar Afonso. This is an open access article distributed under the Creative Commons Attribution License, which permits unrestricted use, distribution, and reproduction in any medium, provided the original work is properly cited.

This paper highlights some recent components related to the endogenous growth literature; in particular, (i) research and development progress, direction, and diffusion; (ii) human-capital accumulation; (iii) wage inequality; (iv) nonscale economic growth, showing how each one has been treated by the existing seminal literature and the expected impact of bringing them together. The connection of the different components is mainly done by involving the leading literature on North-South technologicalknowledge diffusion by imitation under trade, and the prevailing literature on intra- and intercountry wage inequality.

\section{Introduction}

This paper stresses some recent components related to the endogenous growth literature; in particular, research and development (R\&D) direction and diffusion, human capital, and wages. We show how each one has been treated by the seminal literature and the expected impact of bringing them together, which represents a gap in the literature.

Bearing in mind the richness and variety of the endogenous growth literature, the paper starts by providing an integrating view of the nature of the growth generating processes. Some models consider that physical capital and long-run growth are connected to the attainment of a nondeclining marginal productivity of capital. One mechanism for achieving this involves the inclusion of human-capital accumulation. Another relies on the elimination of the diminishing returns to capital from the production function. And yet another entails the introduction of technological-knowledge progress. Technological-knowledge progress is also considered in growth models without physical capital, where longrun growth is thus not induced by nondeclining marginal productivity of capital.

It is usually assumed that endogenous growth theory is based on dynamic, general equilibrium models, where growth is mainly driven by human-capital accumulation and/or technological knowledge arising from R\&D.
This paper stresses studies with endogenous accumulation of human-capital and technological-knowledge-for example, Jones [1], Arnold [2], Blackburn et al. [3], Funke and Strulik [4], and Redding [5] (the latter extends the study of [6] whereas the others extend that of [7]).

To treat international technological-knowledge diffusion, at least two countries and one diffusion channel should be considered. To allow for scale-invariant endogenous growth and human-capital accumulation, inter-country technological-knowledge diffusion by imitation under trade is emphasised. Thus, the paper calls for various components and the aim is to stress the expected nonscale effects of technological-knowledge diffusion on economic growth and on inter- and intracountry wage inequality.

International trade and mobility of factors of production are the main vehicles of technological-knowledge transfer in the world. The factors of production of the resulting endogenous economic growth model are human capital, intermediate goods, and designs to produce intermediate goods. In the tradition of international trade theory, it is usually considered that there are no inter-country movements of assets-human capital and shares of firms that own the designs (e.g., Connolly [8]). In this case, interest rates and wages are determined domestically and the focus is on North-South trade of intermediate goods, as the vehicle of technological-knowledge transfer through imitation. 
North and South is generally understood to be two stylised countries that operate in the same economic environment, but which differ in the following features (e.g., Barro and Sala-i-Martin [9]): (i) exogenous levels of productivity directly related to the quality of domestic institutions; (ii) initial human-capital stocks; (iii) technologicalknowledge stocks; (iv) R\&D capacity; (v) marginal cost of production of final goods.

The first feature relates to domestic institutions which affect the aggregate level of productivity, such as tax laws, property rights protection, and government services. These institutions are more advanced in the North, which is the more developed country.

As to the second feature, it is expected that the initial human-capital levels should be lower in the less developed country; that is, in the South.

The third feature refers to the domestic quality indexes measuring technological knowledge, which, in line with Bernard and Jones [10, 11], Klenow and Rodriguez-Clare [12], and Hall and Jones [13] among others, should be higher in the North.

As to R\&D, the North has the capacity to innovateSchumpeterian R\&D, for example, aimed at improving the quality of intermediate goods, as in Aghion and Howitt [6] — whereas the South's capacity is limited to imitating the North's innovations, as in the seminal models of Grossman and Helpman [14, Chapters 11 and 12].

Concerning the fifth distinctive feature, it is usually assumed that the constant marginal cost of production of final goods is higher in the North than in the South. Following Grossman and Helpman [14, Chapters 11 and 12], Barro and Sala-i-Martin [9], and Connolly [8] among others, this is required for imitation by the South to take place under international trade. Otherwise, the Northern firms would always under-price the Southern ones, and tradewhich must be balanced due to the assumed inexistence of international capital flows and income transfers-would be unfeasible.

In this kind of model, the differences in levels of development between North and South are assumed to have historical roots that are reflected in current institutional characteristics. The concern is not to explain these differences, but rather to take them as given at time zero and analyse the subsequent path of both.

In terms of traditional country groupings in development economics, an appropriate taxonomy for North and South countries would be developed versus developing, rather than developed versus underdeveloped. Indeed, the South should not be too backward, otherwise it would lack the capacity of benefiting from the diffusion of technological knowledge through imitation and trade of intermediate goods (e.g., Helpman [15]).

The North-South general equilibrium growth models thus collects elements from various components, all closely related to the endogenous growth literature. In this paper, these components are explored, showing how each one has been treated by the literature, and the expected added value to the literature by bringing them together is stressed. The exposition starts, however, with physical-capital accu- mulation models that generate long-run growth through the attainment of a nondeclining marginal productivity of capital.

The paper is thus structured as follows. Section 2 provides an integrating view of the nature of the growth generating processes, namely, in models with physical capital. The role of the technological knowledge in models without physical capital is stressed in Section 3. Sections 4 and 5 address, respectively, international technological-knowledge diffusion and scale effects. Section 6 details the role of human-capital accumulation. Section 7 connects the technological-knowledge bias with wage inequality. Policies are considered in Section 8. Section 9 attends to the expected immediate, steady-state and transitional dynamic effects. Section 10 ends the survey with some final remarks.

\section{Growth Induced by the Nondeclining Marginal Productivity of Capital}

The intense theoretical and empirical research that has characterised endogenous growth literature has resulted in a wide variety of growth models. Each model relies on specific assumptions and elaborate mathematical techniques, and consequently delivering growth predictions through several different mechanisms. Capturing the essence of endogenous growth models is therefore difficult due to their richness and diversity.

In this section, one possible integrating view of the nature of the growth generating processes is provided, namely, in models with physical-capital accumulation. These models, which generate long-run growth through the attainment of a nondeclining marginal productivity of capital, are revisited. Basically, one mechanism for achieving long-run growth entails the introduction of technological-knowledge progress. Another involves the inclusion of human-capital accumulation. A third method relies on the elimination of the diminishing returns to capital feature from the production function.

Solow's [16] closed economy exogenous growth model with competitive markets and identical rational agents obtains a nondeclining marginal productivity of capital by considering sustained technological-knowledge progress. As the long-run per capita growth is supported by the exogenous technological-knowledge progress, the model cannot explain within itself the factors that influence economic growth.

R\&D activities aimed at determining the engine of growth, usually within a closed economy model, gave rise to the endogenous growth theory. As already stated (and, e.g., Solow [17] and Helpman [18]), growth theory has produced three main mechanisms to generate a nondeclining marginal productivity of capital.

One mechanism, first proposed by Romer [7, 19] entails including R\&D in the model. Models in which endogenous technological-knowledge progress is the engine of growth are usually identified as R\&D-based growth models. A decentralised theory of technological-knowledge progress has innovations relying on intentional R\&D efforts and firms enjoying the exclusivity of their inventions through the use of patent rights. As the competitive framework no longer holds, 
models consider imperfect competition (the equilibrium growth rate in the decentralised case is not optimal, since capital good producers charge a price that is higher than the marginal cost and thus capital is remunerated by less than its marginal productivity. Moreover, the individual decision to do R\&D ignores that this will benefit other R\&D activities via the creation of a larger technological-knowledge stock).

For the production side, Romer followed Ethier [20] in reinterpreting the utility function of Dixit and Stiglitz [21] as a production function. Romer's model contains three productive sectors: the (competitive) final-good sector, the (imperfect) capital-goods sector, and the R\&D sector. In the reinterpretation, the final output is an increasing function of the number of differentiated capital goods used by a final goods producer.

Two other major initial references in the literature on R\&D-based growth models are the closed economy models by Grossman and Helpman [14] and Aghion and Howitt [6]. These models do not contemplate physical-capital accumulation and are stressed in the next section. Thus, they do not require a constant marginal productivity of capital to reach sustained per capita growth. In the former model, growth is obtained by the production of differentiated consumer goods, which are increasing due to deliberate $\mathrm{R} \& \mathrm{D}$ activities paid up front before profits are realised. To capture consumers' taste for variety, the authors build on Dixit and Stiglitz [21] in defining an index through a constant elasticity of substitution function. In Aghion and Howitt's [6] model, growth is generated by a random sequence of qualityimproving innovations that result from R\&D activities, which are themselves uncertain.

Another (the second) mechanism, introduced by Lucas [22], involves bringing into the model an endogenously determined human-capital accumulation as the source of growth. This type of model, which will be reviewed in Section 6, can be named the human capital-based growth model. Lucas builds on Solow's model and introduces human-capital accumulation, which allows for endogenous growth. In Lucas' model, each worker, who is endowed with one unit of time per unit of time, devotes the fraction of his/her time to current production, and the remaining to human-capital accumulation.

This specification assumes that human-capital accumulation is intensive in human capital, using no physical capital. Further, it allows for sustained per capita growth at a constant rate since it does not display diminishing returns. Thus, Lucas' model overcomes diminishing returns to physical capital through human-capital accumulation. Physical capital can be accumulated forever without decreasing its marginal productivity.

A third method to obtain long-run growth consists of eliminating diminishing returns to capital from the production function. This was first experimented by Jones and Manuelli [23], who introduce a production function without diminishing returns to capital. The denominated AK model constitutes the extreme case of a model that avoids the diminishing returns to scale assumption. It assumes that production exhibits exactly constant returns to scale to a broad concept of capital that includes all kinds of capital.

\section{Technological-Knowledge Progress in Models of Endogenous Growth}

In the literature of endogenous growth, $\mathrm{R} \& \mathrm{D}$ activity is thus essential to technological-knowledge progress. It is mainly carried out or supported by private firms in search of profits, operating in competitive markets. Empirical evidence of this growth mechanism has been shown in, for example, Griliches and Lichtenberg [24], Lichtenberg [25], Coe and Helpman [26], and Coe et al. [27]. At the theoretical level, the first-generation of comprehensive, well-articulated general equilibrium R\&D-growth models that explore the role of technological knowledge in the growth process, are centred on horizontal and vertical R\&D processes.

In the first one, $\mathrm{R} \& \mathrm{D}$ is directed at developing new horizontally differentiated goods, an approach followed in prominent works by Romer [7, 19, 28], Rivera-Batiz and Romer [29], Grossman and Helpman [30, 31] and [14, Chapter 3], and Barro and Sala-i-Martin [32, Chapter 6]. Since there are no quality improvements, goods never becomes obsolete. Firms that become producers remain leaders from then on without supporting further R\&D effort, since they are granted a patent that lasts forever.

In the vertical process, $R \& D$ is instead directed at developing new vertically differentiated qualities of each good, an approach that was first developed by Segerstrom et al. [33], Grossman and Helpman [34, 35] and [14, Chapter 4], and Aghion and Howitt [6]. The resulting models are called Schumpeterian, or quality ladder models, since they appeal to the Schumpeterian concept of creative destruction. Indeed, they assume that the leadership of the firms that use the state-of-the-art qualities is only temporarypermanently subject to destruction by new qualities resulting from successful R\&D.

The main advantage of horizontal R\&D models is their analytical tractability, but the vertical approach is more appropriate for studying the effects of competition between leaders and followers on the growth process-for example, Gancia and Zilibotti [36]. Since trade enhances competition between producers of the same good, the Schumpeterian approach seems to be more appropriate under North-South trade.

Most vertical R\&D models assume that leader firms do not support new R\&D directed at improving their own products. This is motivated by the assumption that firms in each industry have access to the same technology. Despite the coherence of the argument, the implication that leader firms do not invest in $\mathrm{R} \& \mathrm{D}$ is counterfactual.

Thus, some works came to assume that leaders have an R\&D cost advantage and/or that there are diminishing returns in the R\&D effort at the firm level, implying that they devote resources to R\&D too-for example, Segerstrom and Zolnierek [37], Segerstrom [38], and Afonso and Bandeira [39]. Others, such as Dinopoulos and Syropoulos [40, 41] and Sener [42], present models where leaders apply resources in rent-protecting activities, which increase the expected duration of their monopoly power. Aghion et al. [43], for example, find that the Schumpeterian effect of product market competition is outweighed by the incentives for firms 
to carry out R\&D to escape competition. In the extreme Schumpeterian case, Thompson and Waldo [44] present a model with no entry, where R\&D is conducted exclusively by the monopolistic firms.

To examine the growth and wage inequality effects of North-South diffusion, the simplifying assumptions that there are constant returns to $\mathrm{R} \& \mathrm{D}$ expenditure and that only follower firms support the R\&D cost are crucial-for example, Romer [45]. The empirical evidence on returns to scale of R\&D efforts at the firm level seems to be uncertainfor example, Bound et al. [46], Kortum [47], and Thompson [48].

Based on the R\&D technology, Rivera-Batiz and Romer [29] propose a different classification for the R\&D growth models. When the inputs to $\mathrm{R} \& \mathrm{D}$ are labour (or human capital) and the technological-knowledge level, the model is called knowledge-driven-for example, Grossman and Helpman [30], and [14, Chapter 3] and Romer [7]. When $\mathrm{R} \& \mathrm{D}$ technology uses the same inputs and in the same proportion as aggregate output (or, equivalently, if aggregate output itself is the input to R\&D), the model is called labequipment) - for example, Rivera-Batiz and Romer [29] and Barro and Sala-i-Martin [32, Chapters 6 and 7]. Under North-South trade, the lab-equipment model is appropriate since postulating a new production function would merely hinder the algebra without altering the relevant qualitative results (e.g., Papageorgiou [49]).

When included in endogenous growth models, R\&Dhorizontal or vertical, knowledge-driven or lab-equipmentresults in technological-knowledge progress, which, in turn, is the primary determinant of growth. Two major features of technological knowledge are essential for its role as an endogenous engine of growth: nonrivalry and partial nonexcludability. It is nonrival since the marginal costs for its use by an additional firm are negligible. It is partially nonexcludable since the returns to private investment in its production are partly private and partly public.

Thus, on the one hand, innovations are proprietaryprivate investment results in a temporary monopoly if some protection (usually in the form of patents) exists. On the other hand, they add to the stock of public technological knowledge-technological-knowledge spillovers. When technological knowledge takes the form of innovations in the North and leads to imitations in the South, nonrivalry and partial nonexcludability apply to both since they are, respectively, patented in the North and South.

Technological-knowledge diffusion models can also tackle exogenous innovations of the general-purpose technology (GPT) type. The literature on GPT-defined as innovations that have large, extensive, and prolonged economic impacts, such as the steam-engine, electricity, and computers-begins with Bresnahan and Trajtenberg [50]. The effects of a new GPT have usually been studied in a closed-economy framework with a simplified productive structure characterised by one aggregate good-for example, Helpman and Trajtenberg [51]. This simplified structure does not allow the study of the diffusion of a GPT to countries with different levels of development, or its effects on world economic growth and on intra- and inter-country wage inequality.

Motivated by such issues, it is possible to broaden the scope of this literature by considering the North-South implications of the diffusion of a GPT under trade. Indeed, these innovations typically take a long time to have a large impact on the economy, as David [52] documents for developed countries. Arguably, it takes even longer for the GPT to reach developing countries, due to lower levels of technological knowledge.

Moreover, under two human-capital types, the economic structure is richer and allows the study of intra- and intercountry asymmetric effects caused by distinct speeds of GPT adoption in the industries. A distinctive feature of a GPT is its capacity to raise the quality of the goods in which it has been generated and, in successive phases of the diffusion process, aggregate productivity. Hence, the GPT works as an institutional advance, which, as suggested by Coe et al. [27], permanently widens productivity.

The role of institutional change in explaining changes in wage inequality has recently been stressed by Aghion et al. [53]. Thus, the analysis of the wage-inequality effects of the GPT can link the institutional explanation to the more common ones - as explained below-related to trade and to technological-knowledge direction.

\section{North-South Technological-Knowledge Diffusion in Models of Endogenous Growth}

The works of Coe and Helpman [26], Coe et al. [54], Coe et al. [27], Helpman and Hoffmaister [55], and Eaton and Kortum [56,57], among others, reveal that a small number of developed countries account for most of the worldwide innovations. This could suggest that the standard R\&D models are only applicable to the North. However, world productivity data reveals that the benefits of innovative $R \& D$ are much more evenly distributed in the world than expenditures on innovative R\&D_for example, Coe and Helpman [26] and Coe et al. [27]. This data strongly suggests that technological knowledge is diffused internationally. Thus, focusing entirely on domestic technological-knowledge progress when the analysis considers more than one country is inappropriate.

In line with this position, Stokey [58] admits that the most important benefit for Southern countries is the technological-knowledge transfer under trade, in contrast with her own model, where integration produces no technological-knowledge spillovers.

Thus, extensions of the R\&D sector in standard Schumpeterian growth model are required so that it can be applicable to countries that innovate and those that imitate. Hence, analyses should look to the North, where leading technological knowledge is created, and to the South, where it is diffusing. They should also take into account if the imitation process feeds back and affects the original technologicalknowledge source.

Under international trade, the dynamic feedback from imitation to innovation may harm the profits from (and, thus, incentives for) innovative R\&D. That is, in addition to the closed economy Schumpeterian creative destruction 
effect (in this case, only challenging innovations destroy the profits of the current state-of-the-art ones), technologicalknowledge diffusion with trade may bring about further business stealing. Indeed, challenging imitations under trade, coupled with lower marginal costs in the South, are traded internationally. Since diminished incentives to innovative $\mathrm{R} \& \mathrm{D}$ decrease the economic growth rate, these potential negative effects should be weighed against the positive static and dynamic effects of international technological-knowledge diffusion with trade.

The available literature considers, in some way or another, extensions of R\&D endogenous growth models that are applicable to international trade and/or diffusion of technological knowledge-for example, Aghion and Howitt [59, Chapter 11].

A strand of that literature focuses on the effects of NorthSouth trade when it leads to Northern specialisation in industries that exhibit positive spillovers and Southern specialisation in industries lacking such positive externalities. This is the case of models of trade with learning-by-doingfor example, Stokey [60] (the seminal model of Stokey [60] considers specialisation in a traditional sector with no learning-by-doing versus specialisation in industries with learning-by-doing, but does not consider North-South trade), Young [61], and Lucas [62]. In these models, the South experiences negative dynamic effects because trade leads to a specialisation in goods in which learning-by-doing is exhausted, which could outweigh the static gains from trading with the North. Since each country's technologicalknowledge stock relies only on its own range of production, there is no link between domestic and foreign stocks. Hence, neither North-South technological-knowledge diffusion nor the South-North feedback effects are considered by these models.

North-South diffusion is also absent in the open-economy models of Romer [7] and Rivera-Batiz and Romer [29]. These models derive important effects from the flows of goods and technological knowledge on economic growth and are very helpful in identifying the implications of knowledgedriven versus lab-equipment R\&D technology (e.g., Aghion and Howitt [59, Chapter 11]). However, they apply to international relations between developed countries (i.e., North-North in taxonomy already stated) that can benefit from each other's stocks of technological knowledge.

It is thus useful to emphasise other models that consider North-South diffusion. Technological knowledge can be diffused internationally in various ways, namely, through (i) foreign-direct investment (channel introduced in the literature by Vernon [63], with endogenous growth formulations by Helpman [64], Hejazi and Safarian [65], Baldwin et al. [66], Xu [67], and Carr et al. [68]), (ii) international labour mobility (mechanism in the tradition of Bhagwati and Hamada [69] and included in endogenous growth models by Galor and Stark [70], Barro and Sala-i-Martin [32, Chapter 9], and Shea and Woodfield [71]), (iii) communication patterns (proposal considered by, for example, Keller [72, 73]), and (iv) imitation, after the seminal work of Krugman [74], and notably studied by Grossman and Helpman [14, $31,34,35]$ in the context of endogenous growth, and with important additions by Dinopoulos et al. [75], Barro and Sala-i-Martin [9], and Glass [76], among others.

The first two channels rely on international mobility of physical and human-capital assets, which are precluding in this analysis. As for the communication patterns channel, it is of little interest here, since it is largely independent of international trade. That is not the case of imitation-the channel under focus-which is greatly enhanced by the access to state-of-the-art goods permitted by trade. When successful, imitation allows for the technological-knowledge diffusion embodied in goods, as the imitator reverse-engineers those goods. Since, without protection for intellectual property rights (IPRs), imitative $R \& D$ is cheaper than innovative $\mathrm{R} \& \mathrm{D}$, the successful imitator can return to international markets and under-price the original innovator. In an oftencited study, Mansfield and Swartz [77] report that the imitation cost is, on the average, about $65 \%$ of the innovation cost.

Considering the lab-equipment model of R\&D, it can be applied to the innovative North, and can also be conveniently adapted to the particularities of imitative $R \& D$ in the South. Both equilibrium probabilities of successful imitation and innovation should be endogenously determined, based on the maximisation of expected discounted profits. In both countries as well, R\&D can benefit from an autonomous positive learning effect of accumulated public technological knowledge from past R\&D, as in Grossman and Helpman [14, Chapter 12]. The main specificities present in the Southern probability of successful R\&D should be imitation capacity and an advantage of moderate backwardness, which, together, are capable of inducing catch-up with the North.

The existence of spillovers is not sufficient for NorthSouth diffusion and Southern catch-up. Diffusion requires the South to absorb the technological-knowledge spillovers; that is, to have the capacity to include Northern spillovers in its own R\&D. Thus, imitation capacity (i.e., capacity to learn, assimilate, and apply new technologies) can be enhanced by domestic policies promoting R\&D (e.g., Aghion et al. [43]) and the openness degree and other trade policies (e.g., Coe et al. [54] and Sachs and Warner [78]). It can also fall due to the human-capital gap in relation to the North (e.g., Nelson and Phelps [79]). Hence, a new channel through which human-capital levels impinge on technological-knowledge diffusion effects under trade on growth and on wage inequality can be added.

The advantage-of-backwardness hypothesis, introduced by Veblen [80] and enhanced by Findlay [81], assumes that Southern technological knowledge is an increasing function of the gap between its own level and that of the North (e.g., Barro and Sala-i-Martin [9]). It also requires (i) imitation capacity to take advantage of the Northern spillovers, (ii) not fully enforced international IPRs, and (iii) a technologicalknowledge gap below a threshold level, beyond which the imitation cost is prohibitive, or, equivalently, the imitation capacity goes to zero (e.g., Papageorgiou [49]).

Thus, the South cannot be too backward (e.g., Helpman [15], Verspagen [82], and Quah [83, 84]). According to the survey evidence cited by Helpman [15], most imitative $R \& D$ takes place in newly industrialised countries while 
less developed countries engage marginally in this activity. As stated by Quah [83, 84], middle-income countries are converging while low-income countries, which are far from the technological-knowledge frontier, are stagnant and show no potential for rapid growth.

The catch-up and the ensuing convergence are often examined by differences in total factor productivity, TFP (e.g., Bernard and Jones [10, 11], Prescott [85], Hall and Jones [13], Acemoglu and Zilibotti [86], and Afonso and Alves [87]). In general, these works show that differences in international outputs and thus in living standards are overwhelmingly explained by TFP differences. This has led to an increasing focus on explaining TFP differences. However, by using a one-sector model, most of the literature studies the sources of aggregate inter-country TFP differences. Indeed, only the two last quoted works $[86,87]$ analyse sectoral inter-country TFP differences. In particular, these and other studies (e.g., Yeaple and Golub [88]) observe that there are also large sectoral inter-country TFP differences.

But what explains the large sectoral and aggregate intercountry TFP disparities? What explains (sectoral) intracountry TFP differences? The literature does not fully answer these questions as, for example, Leamer and Levinsohn [89] point out. For example, Acemoglu and Zilibotti [86] have considered a model based on distinct inter-country labour levels, which interact with technological-knowledge progress. However, against the empirical evidence (e.g., Yeaple and Golub [88]), their model concludes that Southern TFP should be higher than Northern TFP in the less-skilled intensive sectors.

By considering a nonscale general equilibrium model that gathers elements from various components connected to the endogenous growth literature and the international trade literature, the interrelated impact of exogenous and endogenous productivity can be analysed (e.g., Afonso and Alves [87]). Exogenous productivity relies on the country's institutions (e.g., Hall and Jones [13], Easterly and Levine [90], and Acemoglu et al. [91]). If institutions are so crucial in understanding TFP differences, how can there be such large sectoral TFP differences within a country that has a unified set of institutions?

Due to that, through the connection of various components, it can be assumed that endogenous productivity relies on (i) Schumpeterian $\mathrm{R} \& \mathrm{D}$ (innovations and imitations); (ii) accumulation of two human-capital types-for example, skilled, school intensive and unskilled, on-the-job-training (OJT) intensive; (iii) the mismatch between available technological knowledge and human-capital levels; (iv) the NorthSouth trade regime. By collecting the diverse elements and by improving on some of them, the question of how they affect sectoral intracountry, and sectoral and aggregate intercountry TFP, can be addressed.

Results can be studied vis-à-vis the previous literature on productivity differences. In general, that literature only analyses the sources of aggregate inter-country TFP and each work stresses a particular cause of the differences: technological knowledge, human capital, quality of institutions, or mismatch between technological knowledge and skills. By considering that each final good is produced by one of two technologies, it is possible to analyse sectoral intra- and intercountry productivity differences; by connecting the endogenous growth literature and the international trade literature, it is possible to stress the contribution of each cause of productivity differences in each trade regime: without trade effects, under trade of intermediate goods, and under trade of all goods.

\section{Scale Effects in Models of Endogenous Growth}

In order to analyse the mechanisms through which international trade affects technological-knowledge progress in contexts where market-size effects are not present, an essential feature to consider is that growth is independent of the scale of the economy.

The endogenous growth literature has been debating the role of scale effects since Jones $[92,93]$ criticised the first generation R\&D endogenous growth models-particularly the seminal work of Romer [7]—on the grounds that it unreasonably predicted a very strong positive market-size effect on the rate of economic growth.

In Romer's [7] case, a knowledge-driven process, the pool of labour employed in R\&D increases the innovation rate and so the economic-growth rate. In lab-equipment models (e.g., Rivera-Batiz and Romer [29]), the scale effect is connected to the size of profits that, in each period, accrue to the leader producer. In this case, a larger market expands the monopolist's profits and thus the incentives to allocate resources to $\mathrm{R} \& \mathrm{D}$, thereby increasing the growth rate. In addition to theoretical arguments, several authors have supplied the debate with empirical evidence against scale effects-for example, Backus et al. [94], Jones [92], Dinopoulos and Thompson [95], and Zachariadis [96].

Apart from the endogenous growth debate on the subject, the independence between growth and scale effects can be considered mainly instrumental to the isolation of the other effects of international technological-knowledge diffusion under trade.

Starting with Jones [93] himself, who has suitably modified Romer's [7] R\&D specification, several modelling efforts have been made to remove the scale effects (see Jones [97] and Segerstrom [98] for detailed discussion and distinct ways to avoid scale effects). In view of the endogenous growth components stressed, two relevant examples are Dinopoulos and Thompson [95] and Dinopoulos and Syropoulos [40]. The former assumes that an increase in scale also entail costs. The latter considers that leaders spend resources in rentprotecting activities that delay the next successful research.

These scale-removing efforts have focused mostly on either closed-economy or North-North models [41, 99-101]. Little progress has been made at building scale-independent North-South models (exceptions are $[42,102]$ ).

Scale effects can thus be removed by assuming that $R \& D$ is penalised by the market size measured by the labour (or human-capital) level (e.g., Afonso [103] and Afonso and Alves [87]). This is consistent with the literature that observes that increases in scale also entail costs of coordination among agents, processing of ideas, marketing, information, 
organisation, and transportation (e.g., Becker and Murphy [104], Quah [105], Alesina and Spolaore [106], Dinopoulos and Thompson $[95,107]$, and Dinopoulos and Segerstrom [99]). In line with Dinopoulos and Syropoulos [40, 41] and Sener [42], additional costs of scale are related to leaders' strategies to increase the difficulty of R\&D by followers, with the aim of prolonging their temporary monopoly power.

In the terminology of Dinopoulos and Segerstrom [99], this scale-removing assumption results in a "permanent-effects-on-growth" specification, in which both technological knowledge and economic growth are endogenous-as opposed to the semiendogenous models (e.g., Jones [93] and Funke and Strulik [4]) (in semiendogenous models, technological knowledge is endogenous, but the steady-state growth rate results in exogeneity, which, in fact, is not that different from the neoclassical growth model). Compared with Jones' [93] model, the proposed specification replaces labour by human capital, since population and growth are at best uncorrelated (e.g., Mankiw et al. [108]) while human capital is widely held to be an essential source of growth-see Section 6 below.

\section{Human-Capital Accumulation in Endogenous Growth Models}

In addition to Schumpeterian R\&D, economic growth is also driven by endogenous human-capital accumulation-that is, when individuals improve their own skills in response to incentives, aggregate productivity rises (indeed, when decisions of skill acquisition are embedded into the model, the economy can continue to grow even if the labour stock is limited, and even without technological-knowledge progress). The empirical evidence on this potential growth mechanism has been presented by many authors (e.g., Romer [109], Barro [110, 111], Mankiw et al. [108], Levine and Renelt [112], and Barro and Sala-i-Martin [32, Chapter 12]). They usually conclude that an increase in the average years of schooling of the working population, which is traditionally the main empirical measure of human capital, has positive and significant effects on growth. However, Benhabib and Spiegel [113] point out that growth is strongly correlated not to the change in educational attainment, but to the levelthat is, not to accumulation but to the human-capital stock.

These empirical results may, though, be biased for a number of reasons, such as measurement errors (e.g., Krueger and Lindahl [114]), the fact that some countries, namely, developing countries, are outliers (e.g., Temple [115]), and the importance of the skilled population in the public sector (e.g., Griliches [116] and Pritchett [117]). In addition, some of the panel data estimations considering together differences over time and across countries yield a negative relation between growth and human capital (e.g., De Gregorio [118], Knight et al. [119], Islam [120], and Caselli et al. [121]).

Another source of bias is the role of human capital in production that is complex. By considering learning variables and interaction between technological levels and human capital, Benhabib and Spiegel [113] and Engelbrecht [122] obtain some advances. Further complexity is present in the educational process itself, which converts physical endowments in human capital. Many authors emphasise, mainly for developing (Southern) countries, modes of education other than formal schooling, especially OJT (e.g., Bartel and Litchtenberg [123], Mincer [124, 125], and Bartel and Sicherman [126]).

At the theoretical level, Lucas [22,62] is credited with the seminal analysis of endogenous growth based on humancapital accumulation, to be followed by Becker et al. [127], Stokey [128]. Concerning the productivity path in newly industrialised countries, Lucas [62] stresses the role of employed human capital, with a model where OJT is enhanced by the continuous introduction of new production lines. Mincer $[124,125]$ explores these ideas further, assuming that OJT, differently from learning-by-doing, is costly and relies on individual decisions in interaction with other economic decisions. In Mincer's case, the opportunity cost of OJT is the wage lost while acquiring human capital at technical, professional, or specialised schools related to the job.

As to human-capital heterogeneity, the R\&D literature dealing with technological-knowledge direction and wage inequality assumes that workers are divided into two homogeneous groups, skilled and unskilled (e.g., Kiley [129], Thesmar and Thoenig [130], Acemoglu and Zilibotti [86], and Afonso [103]). These models can be extended by endogenously specifying the supply of each human-capital type (e.g., Afonso [131]).

To keep things as simple as possible, only two humancapital types should be considered, one more productive than the other: skilled and unskilled, respectively. Following Mincer [124, 125], each type of accumulation function can employ the inputs OJT and school in a specific way. The skilled human capital can be relatively abundant in the North, and its accumulation can be school intensive, which is usually the more productive input while the unskilled type's can be OJT intensive.

\section{Direction of Technological-Knowledge Progress and Wage Inequality}

Considering a standard economic structure for both countries-in endogenous R\&D growth theory-perfectly competitive final goods can use quality-adjusted intermediate goods as inputs, together with human capital. Intermediate goods, in turn, can use innovative or imitative designs as inputs, under monopolistic competition.

Thus, each final good can be produced by one of two substitutable technologies: the (un)skilled technology uses (un)skilled human capital jointly with a continuum set of (un)skilled-specific intermediate goods. This function, where complementarity of inputs is coupled with substitutability between technologies, is proposed, for example, from Acemoglu and Zilibotti's [86] horizontal R\&D growth model. Although their model includes neither endogenous human capital nor technological-knowledge diffusion, it is very suitable to the repercussion of the technological-knowledge bias on wage inequality.

When firms invest relatively more in enhancing skilledspecific intermediate goods the choice of final goods' 
technology shifts in favour of the skilled type, thus raising the demand for skilled human capital. In this context, the technological-knowledge bias is related to the wage premium of skilled human capital - that is, to the intracountry skill-premium (e.g., Afonso [103] and Afonso and Alves [87]). It is clearly unfeasible to discuss wage inequality in endogenous growth models with accumulation of aggregate human capital. This is the main reason behind the extension to heterogeneous human capital.

This relationship has received considerable attention in the skill-biased technological change literatureprominently by Acemoglu [132-135] - although not in the context of human-capital accumulation and technologicalknowledge diffusion. In addition, since technologicalknowledge diffusion occurs with trade, the discussion of factor levels, factor price movements, and inter-country income inequality effects can be made, which are traditional issues in international trade analysis.

The skill-bias literature seeks to explain two major trends that have emerged since the early 1980s on intracountry wage inequality in developed and (newly industrialised) developing countries (e.g., Richardson [136] and Aghion et al. [53]): the rise in skilled wage inequality and the rise in the proportion of skilled labour. However, the two major explanations explored to date-skill-bias literature and international trade literature (e.g., Wood [137])—contradict at least one of these observed trends.

According to the skill-bias literature, the technologicalknowledge bias and the resulting path of the wage premium are driven by the rise in skilled-labour supply. Thus, this explanation emphasises the market-size effect on technological-knowledge bias: technologies that use the more abundant human-capital type are favoured. However, the operation of this very same effect with trade openness partially contradicts the argument - with an increase in trade between a skilled-abundant country and an unskilled one, the market-size channel would predict a fall in the skilled technological-knowledge bias.

Many works with empirical evidence on skill-biased technological change have considered the rise of the skill premium in developed countries as arising from the marketsize effect in closed economies (e.g., Bartel and Litchtenberg [123], Katz and Murphy [138], Berman et al. [139], Juhn et al. [140], Autor et al. [141], Bartel and Sicherman [126], Berman et al. [142], Machin and Van Reenen [143], and Gera et al. [144]).

As stated, some more recent interpretations, still in a closed-economy context, attribute the boost in wage inequality to organisational and institutional change triggered by a new GPT (e.g., Acemoglu [145], Aghion [146], and Caroli and Van Reenen [147]).

Some authors, like Wood [148] and Leamer [149, 150], challenge these empirical studies on the grounds that they neglect open-economy effects. These authors consider the increase in wage inequality to be essentially a result of static comparative advantages (in specifications without R\&D and technological-knowledge diffusion). This point of view can be related to the price-channel effect on $\mathrm{R} \& \mathrm{D}$ - explained below-especially in a context of trade between countries with distinct human-capital levels.

As to the international trade explanation, adopted, for example, by Leamer [150] and Wood [137], the explanation relies mainly on the application of the Stolper-Samuelson theorem: imports of goods produced by unskilled labour reduce unskilled wages in the skilled-abundant country. However, the same argument applied to the exporter country would predict a rise in the unskilled wage premium, which contradicts the trend in (newly industrialised) developing countries.

Both sides of this debate have been, in fact, dominated by labour levels, either in a Heckscher-Ohlin way or by R\&D intensity. In the latter case, a larger skilled-labour level, for example, creates a larger demand for $\mathrm{R} \& \mathrm{D}$ directed towards improvements in inputs used in goods produced by skilled labour, thus increasing relative skilled wages.

As suggested above, in addition to this market-size channel, the direction of $\mathrm{R} \& \mathrm{D}$ is also influenced by the price of goods-price channel-since more expensive goods command higher profits for the producers of the respective inputs. That is, by removing scale effects, the focus shifts to the price channel. In this case, technologies that use the scarcer human-capital type are favoured (e.g., Afonso [103]). Thus, endogenous human-capital accumulation not only affects the path of output and wages - as in traditional endogenous human-capital growth models_-but also affects the direction of R\&D.

For instance, the relative abundance of skilled human capital increases the price of goods produced by unskilled human capital and thus the demand for R\&D directed towards advances in goods produced by unskilled human capital. That is, when the skilled human capital-abundant country A exports inputs incorporating its $\mathrm{R} \& \mathrm{D}$ results to an unskilled-abundant country B, it benefits from the higher prices of goods produced by skilled human capital in B. The resulting profit opportunities redirect $R \& D$ towards inputs that boost the marginal productivity and wages of skilled human capital.

By considering trade between two countries with different development levels, but both capable of conducting $\mathrm{R} \& \mathrm{D}$ (innovative in the North and imitative in the South), it is feasible to link technological-knowledge diffusion with the technological-knowledge path (recent empirical studies by, e.g., Amiti and Konings [151], Goldberg and Pavcnik [152], and Goldberg et al. [153] provide evidence showing that imports can improve Southern productivity, hence supporting the theoretical focus on the role of trade on Southern progress. Moreover, Acemoglu [154] suggested that increased international trade can cause endogenous skill-biased technological change). Hence, we can relate technological-knowledge diffusion to the dynamics of intracountry wage inequality. This connection can thus be analysed in a model bringing together Afonso and Alves [87] and Afonso [131]; that is, in a model where (i) technologicalknowledge progress and human-capital accumulation drive endogenous growth and its direction determines relative wages; (ii) the intensity of the driving force is affected by 
international trade; (iii) price changes induced by trade affect the technological-knowledge bias and thus relative wages.

Results can be analysed in comparison with the previous skill-biased technological change literature. In that literature, the bias that causes wage inequality is induced by the marketsize channel. By removing scale effects, changes in the paths of intracountry wage inequality result similarly from the technological-knowledge bias, but are induced by the price channel under trade (e.g., Afonso [103]). In contrast with the market-size channel and bearing in mind the results in Afonso and Alves [87], the operation of the price-channel certainly results in an increase in the skilled technologicalknowledge bias following openness. This perspective is more in line with the recent trends observed in developed and (newly industrialised) developing countries.

To sum up, by shifting to the price channel (instead of the market size) and by accounting for technological-knowledge diffusion, it is possible to generate predictions compatible with the aforementioned trend of wage inequality in developed and (newly industrialised) developing countries.

\section{Policies: R\&D Subsidies and the Protection of Intellectual Property Rights}

Due to the relationship between intermediate goods and $R \& D, R \& D$ can be encouraged either by a direct subsidy or by a subsidy for the production of intermediate goods (e.g., Afonso [155]). In any of these cases, policies also impinge on the demand for labour (or human capital). In addition, when policies affect not only the level but also the direction of R\&D, they also impact on the relative demands for the labour (human-capital) type, and thus on wage inequality.

The effective intracountry trend in wage inequality is also concomitant with a new technological-knowledge policy in several developed (and developing countries), which may have affected the price channel. For example, in 1981, the US policy began targeting commercial innovations more directly by introducing the Research and Experimentation tax credit. Therefore, the US policy stimulates R\&D and contributes to technological-knowledge progress (this pattern has indeed been followed by a number of countries (e.g., Irwin and Klenow [156] for the USA, Maggioni et al. [157] and Medda et al. [158] for Italy, Hujer and Radic [159] for Germany, Czarnitzki et al. [160] for Canada, and Czarnitzki et al. [161] for Germany and Finland). At the same time, the US policy started directing public spending towards skilled goods, thus increasing the relative demand for skilled labour and the skill-labour premium. That is, the change in the public spending composition reallocated the price-channel mechanism induced by labour levels from unskilled to skilled goods.

By shifting to the price-channel mechanism and by taking government policy into consideration, it is viable to analyse how in fact the skill-biased technological-knowledge change and the ensuing skill-biased wage inequality can be caused by government intervention. Thus, governmental encouragement of $R \& D$ has a bearing on the demand for labour. In addition, when policies affect not only the level but also the direction of $R \& D$ (through the structure of public spending), they also have an effect on the relative demand for the different types of labour and thus on wage inequality (e.g., Berger [162], Goolsbee [163], Cozzi and Impullitti [164], and Afonso [155]).

It is doable to provide an endogenous nonscale mechanism to link technological-knowledge-progress, diffusion, and bias-human-capital accumulation, government intervention, and wage inequality. With the price channel present, an increase in a subsidy to skilled intermediate goods and/or to skilled $R \& D$ can redirect $R \& D$ towards designs that improve skilled intermediate goods. The arising technological-knowledge bias stimulates the relative demand for skilled human capital, thereby increasing the skilled premium, even when the relative supply of skilled human capital also increases.

Another important dimension of government intervention is the protection of IPRs, which, as stated above, are granted at the domestic level, but not internationally. Since technological knowledge is partially non-excludable, domestic protection of IPRs increases the degree of excludability of the results of R\&D in the North and in the South.

In turn, international enforcement of IPRs, by protecting innovative $R \& D$ only, would prevent imitation $R \& D$, and technological-knowledge diffusion through this mechanism would not occur. This is the reason why this kind of model assumes that IPRs are never fully enforced internationally. Still, it is allowed for different degrees of enforcement, not forgetting ongoing debates on the effects of strong international IPRs' protection on the rates of worldwide technological-knowledge progress and economic growth. In Segerstrom et al. [33], Helpman [15], Lai [165], Dinopoulos and Segerstrom [102], and Lai and Qiu [166] the effect is negative, contrary to Glass and Saggi [167], Smith [168], Sener [42], Maskus [169], and Branstetter et al. [170].

For example, Helpman [15] assumed that stronger IPRs would raise imitation costs, thus diminishing technologicalknowledge flows and global innovation. Lai [165] noted that innovation could be enhanced if foreign direct investment is the diffusion channel. Lai and Qiu [166] state that it is commonly presumed by trade economists that reforms in IPRs raise imitation costs, reduce access to global information, and place firms in developing countries at a competitive disadvantage in the global market. Yang and Maskus [171] found that patent reforms would both raise imitation costs and reduce the technological-knowledge licensing cost, which encourages diffusion and innovation.

In the discussed context, the contribution to this literature results from the inclusion of both technologies and human-capital accumulation, which are influenced by the degree of international IPRs' protection. This, in turn, affects the technological-knowledge progress and diffusion, wages, and economic growth.

\section{Analysis of Immediate, Steady-State, and Transitional Dynamic Effects}

The assessment of the nonscale effects of technologicalknowledge diffusion under trade and with human capital on growth and on wage inequality can comprise three 
analytical stages: immediate level effects, steady-state effects, and transitional dynamics. By means of comparative statics and dynamics, it is possible to uncover the mechanisms through which these effects are affected by initial NorthSouth conditions, the technology (of production, of R\&D, and of human-capital accumulation), and by government policies.

The derivation of transitional dynamics is often avoided in growth models with technological-knowledge diffusion. Grossman and Helpman [14, 35], for example, analyse the North-South feedback effects only in steady-state. Barro and Sala-i-Martin [9] derive transitional dynamics for the South, but no transition path exists for the North, since their model, without international trade, does not allow for feedback effects.

The derivation of transitional dynamics, for the North and South, usually requires the use of numerical methods, due to the complexity of the system of differential equations. Funke and Strulik [4], for example, use the fourth-order Runge-Kutta classical method. A sensitivity analysis can then be conducted for comparative statics and dynamics and also to enhance confidence in the numerically derived results.

\section{Concluding Remarks}

This paper revises and discusses the literature directly or indirectly related to North-South growth models with domestic endogenous accumulation of internationally immobile assets and domestic but no international protection of $\mathrm{R} \& \mathrm{D}$ results. The analysis is designed in order to focus on the seminal literature. It investigates how trade affects the structure and the dynamics of scale-independent technological-knowledge progress and also its North-South diffusion, thus influencing the paths of economic growth and inter- and intracountry wage inequality.

This survey intends to follow and contribute, namely, to four main lines of research previously explored notably by models of technological-knowledge diffusion growth (e.g., Barro and Sala-i-Martin [9]), nonscale technological-knowledge progress (e.g., Jones [93]), human-capital growth (e.g., Lucas $[22,62]$ ), and technological-knowledge bias and wageinequality growth (e.g., Acemoglu and Zilibotti [86]).

By considering trade between North and South-two countries with different levels of development, but both capable of conducting R\&D-we can connect technologicalknowledge diffusion with the direction and progress of technological knowledge and with human-capital accumulation. Moreover, we can relate the dynamics of inter- and intracountry wage inequality and analyse the pattern of trade specialisation.

With particular regard to the literature on technologicalknowledge diffusion, it is possible to stress the effects of the interaction between endogenous $\mathrm{R} \& \mathrm{D}$ and human-capital, and the mechanism of trade as the main vehicle of diffusion without scale effects. Indeed, with the exceptions of Dinopoulos and Segerstrom [102] and Sener [42], still without the R\&D-human-capital interaction, the literature has studied the following: technological-knowledge diffusion without trade and with scale effects (e.g., Barro and Sala-iMartin [9]); technological-knowledge diffusion with trade, but still with scale effects (e.g., Grossman and Helpman [14, Chapters 11 and 12]); scale-invariant technologicalknowledge progress, but without diffusion or trade (e.g., Jones [93]).

\section{References}

[1] C. Jones, "Sources of U.S. economic growth in a world of ideas," American Economic Review, vol. 92, no. 1, pp. 220239, 2002.

[2] L. Arnold, "Growth, welfare, and trade in an integrated model of human-capital accumulation and research," Journal of Macroeconomics, vol. 20, no. 1, pp. 81-105, 1998.

[3] K. Blackburn, V. Hung, and A. Pozzolo, "Research, development and human capital accumulation," Journal of Macroeconomics, vol. 22, no. 2, pp. 189-206, 2000.

[4] M. Funke and H. Strulik, "On endogenous growth with physical capital, human capital and product variety," European Economic Review, vol. 44, no. 3, pp. 491-515, 2000.

[5] S. Redding, "The low-skill, low-quality trap: strategic complementarities between human capital and R\&D," Economic Journal, vol. 106, no. 435, pp. 458-470, 1996.

[6] P. Aghion and P. Howitt, "A model of growth through creative destruction," Econometrica, vol. 60, pp. 323-352, 1992.

[7] P. Romer, "Endogenous technological change," Journal of Political Economy, vol. 98, pp. S71-S102, 1990.

[8] M. Connolly, "The dual nature of trade: measuring its impact on imitation and growth," Journal of Development Economics, vol. 72, no. 1, pp. 31-55, 2003.

[9] R. Barro and X. Sala-i-Martin, "Technological diffusion, convergence, and growth," Journal of Economic Growth, vol. 2, no. 1, pp. 1-26, 1997.

[10] A. Bernard and C. Jones, "Productivity across industries and countries: time series theory and evidence," Review of Economics and Statistics, vol. 78, no. 1, pp. 135-146, 1996.

[11] A. Bernard and C. Jones, "Comparing apples to oranges: convergence and measurement across industries and countries," American Economic Review, vol. 86, no. 5, pp. 1216-1238, 1996.

[12] P. Klenow and A. Rodriguez-Clare, "The neoclassical revival in growth economics: has it gone too far?" in NBER Macroeconomics Annual, B. Bernanke and J. Rotemberg, Eds., pp. 73-103, MIT Press, Cambridge, Mass, USA, 1997.

[13] R. Hall and C. Jones, "Why do some countries produce so much more output per worker than others?" Quarterly Journal of Economics, vol. 114, no. 1, pp. 83-116, 1999.

[14] G. Grossman and E. Helpman, Innovation and Growth in the Global Economy, MIT Press, Cambridge, Mass, USA, 1991.

[15] E. Helpman, "Innovation, imitation and intellectual property rights," Econometrica, vol. 30, pp. 1247-1280, 1993.

[16] R. Solow, "A contribution to the theory of economic growth," Quarterly Journal of Economics, vol. 70, pp. 65-94, 1956.

[17] R. Solow, Growth Theory: An Exposition, Oxford University Press, New York, NY, USA, 2000.

[18] E. Helpman, The Mystery of Economic Growth, Balknap for Harvard University Press, Cambridge, Mass, USA, 2004.

[19] P. Romer, "Growth based on increasing returns due to specialization," American Economic Review, vol. 77, pp. 56-62, 1987.

[20] W. Ethier, "National and international returns to scale in the modern theory of international trade," American Economic Review, vol. 72, pp. 389-405, 1982. 
[21] A. Dixit and J. Stiglitz, "Monopolistic competition and optimal product diversity," American Economic Review, vol. 67, pp. 297-308, 1977.

[22] R. Lucas, "On the mechanics of economic development," Journal of Monetary Economics, vol. 22, no. 1, pp. 3-42, 1988.

[23] L. Jones and R. Manuelli, "A convex model of equilibrium growth: theory and policy implications," Journal of Political Economy, vol. 98, pp. 1008-1038, 1990.

[24] Z. Griliches and F. Lichtenberg, "R\&D and productivity growth at the industrial level: is there still a relationship?" in Patents and Productivity, Z. Griliches, Ed., pp. 465-496, University of Chicago Press, Chicago, Ill, USA, 1984.

[25] F. Lichtenberg, "R\&D investment and international productivity differences," in Economic Growth in the World Economy, H. Siebert, Ed., pp. 89-110, J. C. B. Mohr, Tubingen, Germany, 1993.

[26] D. Coe and E. Helpman, "International R\&D spillovers," European Economic Review, vol. 39, no. 5, pp. 859-897, 1995.

[27] D. Coe, E. Helpman, and A. Hoffmaister, "International R\&D spillovers and institutions," European Economic Review, vol. 53, no. 7, pp. 723-741, 2009.

[28] P. Romer, "Increasing returns and long-run growth," Journal of Political Economy, vol. 94, pp. 1002-1037, 1986.

[29] L. Rivera-Batiz and P. Romer, "Economic Integration and endogenous growth," Quarterly Journal of Economics, vol. 106, pp. 553-555, 1991.

[30] G. Grossman and E. Helpman, "Comparative advantage and long run growth," American Economic Review, vol. 80, no. 4, pp. 796-815, 1990.

[31] G. Grossman and E. Helpman, "Endogenous product cycles," Economic Journal, vol. 101, no. 408, pp. 1214-1229, 1991.

[32] R. Barro and X. Sala-i-Martin, Economic Growth, MIT Press, Cambridge, Mass, USA, 2nd edition, 2004.

[33] P. Segerstrom, T. Anant, and E. Dinopoulos, "A Schumpeterian model of product life cycle," American Economic Review, vol. 80, pp. 1077-1092, 1990.

[34] G. Grossman and E. Helpman, "Quality ladders in the theory of growth," Review of Economic Studies , vol. 58, pp. 43-61, 1991.

[35] G. Grossman and E. Helpman, "Quality ladders and product cycles," Quarterly Journal of Economics, vol. 106, pp. 557-586, 1991.

[36] G. Gancia and F. Zilibotti, "Horizontal innovation in the theory of growth and development," in Handbook of Economic Growth, P. Aghion and S. Durlauf, Eds., pp. 111-170, NorthHolland, Amsterdam, The Netherlands, 2005.

[37] P. Segerstrom and J. Zolnierek, "The R\&D incentives of industry leaders," International Economic Review, vol. 40, no. 3, pp. 745-766, 1999.

[38] P. Segerstrom, "Intel economics," International Economic Review, vol. 48, no. 1, pp. 247-280, 2007.

[39] Ó. Afonso and A. M. Bandeira, "Maintenance and destruction of R\&D leadership," The Manchester School, forthcoming.

[40] E. Dinopoulos and C. Syropoulos, "Rent protection as a barrier to innovation and growth," Economic Theory, vol. 32, no. 2, pp. 309-332, 2007.

[41] E. Dinopoulos and C. Syropoulos, "Globalization, factor endowments, and scale-invariant growth," in Proceedings of the 9th Conference on Dynamics, Economic Growth and International Trade, (DEGIT'04), University of Florida, Reykjavik, Iceland, June 2004.
[42] F. Sener, "Intellectual property rights and rent protection in a North-South product-cycle model," Union College, New York, Mimeo, 2004, http://www.aeaweb.org/annual _mtg_papers/2005/0107_0800_0501.pdf.

[43] P. Aghion, C. Harris, P. Howitt, and J. Vickers, "Competition, imitation and growth with step-by-step innovation," Review of Economic Studies, vol. 68, no. 3, pp. 467-492, 2001.

[44] P. Thompson and D. Waldo, "Growth and trustified capitalism," Journal of Monetary Economics, vol. 34, no. 3, pp. 445462, 1994.

[45] P. Romer, "Idea gaps and object gaps in economic development," Journal of Monetary Economics, vol. 32, no. 3, pp. 543573, 1993.

[46] J. Bound, C. Cummins, Z. Griliches, B. Hall, and A. Jaffe, "Who does R\&D and who patents?" in Patent and Productivity, Z. Griliches, Ed., pp. 21-54, University of Chicago Press, Chicago, Ill, USA, 1984.

[47] S. Kortum, "Equilibrium $\mathrm{R} \& \mathrm{D}$ and the patent-R\&D ratio: U.S. evidence," American Economic Review, vol. 83, pp. 450457, 1993.

[48] P. Thompson, "Technological opportunity and the growth of knowledge: a Schumpeterian approach to measurement," Journal of Evolutionary Economics, vol. 6, no. 1, pp. 77-97, 1996.

[49] C. Papageorgiou, "Technology adoption, human capital, and growth theory," Review of Development Economics, vol. 6, no. 3, pp. 351-368, 2002.

[50] T. Bresnahan and M. Trajtenberg, "General purpose technologies: engines of growth?” Journal of Econometrics, vol. 65, no. 1, pp. 83-108, 1995.

[51] E. Helpman and M. Trajtenberg, "A time to sow and a time to reap: growth based on general purpose technologies," in General Purpose Technologies and Economic Growth, E. Helpman, Ed., pp. 55-83, MIT Press, Cambridge, Mass, USA, 1998.

[52] P. David, "The dynamo and the computer: a historical perspective on the modern productivity paradox," American Economic Review, vol. 80, pp. 355-361, 1990.

[53] P. Aghion, P. Howitt, and G. Violante, "Wage inequality and technological change: a Nelson-Phelps approach," in Knowledge, Information, and Expectations in Modern Economics, P. Aghion, R. Frydman, J. Stiglitz, and M. Woodford, Eds., pp. 443-461, Princeton University Press, Princeton, NJ, USA, 2003.

[54] D. Coe, E. Helpman, and A. Hoffmaister, "North-south R\&D spillovers," Economic Journal, vol. 107, no. 440, pp. 134-149, 1997.

[55] E. Helpman and A. Hoffmaister, "North-south R\&D spillovers,” Economic Journal, vol. 107, no. 440, pp. 134-149, 1997.

[56] J. Eaton and S. Kortum, "International patenting and technology diffusion: theory and measurement," International Economic Review, vol. 40, no. 3, pp. 537-570, 1999.

[57] J. Eaton and S. Kortum, "Trade in capital goods," European Economic Review, vol. 45, no. 7, pp. 1195-1235, 2001.

[58] N. Stokey, "Free trade, factor returns, and factor accumulation," Journal of Economic Growth, vol. 1, no. 4, pp. 421-447, 1996.

[59] P. Aghion and P. Howitt, Endogenous Growth Theory, MIT Press, Cambridge, Mass, USA, 1998.

[60] N. Stokey, "Learning by doing and the introduction of new goods," Journal of Political Economy, vol. 96, pp. 701-717, 1988. 
[61] A. Young, "Learning by doing and the dynamic effects of international trade," Quarterly Journal of Economics, vol. 106, pp. 369-405, 1991.

[62] R. Lucas, "Making a Miracle," Econometrica, vol. 6, pp. 251272, 1993.

[63] R. Vernon, "International investment and international trade in the product cycle," Quarterly Journal of Economics, vol. 80, pp. 190-207, 1966.

[64] E. Helpman, "R\&D and productivity: the international connection," in The Economics of Globalisation: Policy Perspectives from Public Economics, A. Razin and E. Sadka, Eds., pp. 1730, Cambridge University Press, New York, NY, USA, 1999.

[65] W. Hejazi and A. Safarian, "Trade, foreign direct investment, and R\&D spillovers," Journal of International Business Studies, vol. 30, no. 3, pp. 491-511, 1999.

[66] R. Baldwin, H. Braconier, and R. Forslid, "Multinationals, endogenous growth and technological spillovers: theory and evidence," Centre for Economic Policy Research Discussion Paper 2155, 1999.

[67] B. Xu, "Multinational enterprises, technology diffusion, and host country productivity growth," Journal of Development Economics, vol. 62, no. 2, pp. 477-493, 2000.

[68] D. Carr, J. Markusen, and K. Maskus, "Estimating the knowledge-capital model of the multinational enterprise," American Economic Review, vol. 91, no. 3, pp. 693-708, 2001.

[69] J. Bhagwati and K. Hamada, "The brain drain, international integration of markets for professionals and unemployment: a theoretical analysis," Journal of Development Economics, vol. 1, no. 1, pp. 19-42, 1974.

[70] O. Galor and O. Stark, "Migration, human capital formation, and long-run output," in Migration: A Challenge for Europe, H. Siebert, Ed., pp. 59-68, J. C. B. Mohr, Tubingen, Germany, 1994.

[71] K. Shea and A. Woodfield, "Optimal immigration, education and growth in the long run," Journal of International Economics, vol. 40, no. 3-4, pp. 495-506, 1996.

[72] W. Keller, "Geographic localization of international technology diffusion," American Economic Review, vol. 92, no. 1, pp. 120-142, 2002.

[73] W. Keller, "Trade and the transmission of technology," Journal of Economic Growth, vol. 7, no. 1, pp. 5-24, 2002.

[74] P. Krugman, "A model of innovation, technology transfer, and the world distribution of income," Journal of Political Economy, vol. 87, pp. 253-266, 1979.

[75] E. Dinopoulos, J. Oehmke, and P. Segerstrom, "High-technology-industry trade and investment: the role of factor endowments," Journal of International Economics, vol. 34, no. 1-2, pp. 49-71, 1993.

[76] A. Glass, "Product cycles and market penetration," International Economic Review, vol. 38, no. 4, pp. 865-891, 1997.

[77] E. Mansfield and M. Swartz, "Imitation costs and patents: an empirical study," Economic Journal, vol. 91, pp. 907-918, 1981.

[78] J. Sachs and A. Warner, "Economic reform and the process of global integration," Brookings Papers on Economic Activity, pp. 1-95, 1995.

[79] R. Nelson and E. Phelps, "Investment in humans, technological diffusion, and economic growth," American Economic Review, vol. 56, pp. 69-75, 1966.

[80] T. Veblen, Imperial Germany and the Industrial Revolution, Macmillan, London, UK, 1915.

[81] R. Findlay, "Relative backwardness, direct foreign investment and the transfer of technology: a simple dynamic model," Quarterly Journal of Economics, vol. 92, pp. 1-16, 1978.
[82] B. Verspagen, Uneven growth between interdependent economies: an evolutionary view of technology gaps, trade and growth, Ph.D. dissertation, Aldershot: Avebury, 1994.

[83] D. Quah, "Twin peaks: growth and convergence in models of distribution dynamics," Economic Journal, vol. 106, no. 437, pp. 1045-1055, 1996.

[84] D. Quah, "Empirics for growth and distribution: stratification, polarization, and convergence clubs," Journal of Economic Growth, vol. 2, no. 1, pp. 27-59, 1997.

[85] E. Prescott, "Needed: a theory of total factor productivity," International Economic Review, vol. 39, no. 3, pp. 525-551, 1998.

[86] D. Acemoglu and F. Zilibotti, "Productivity differences," Quarterly Journal of Economics, vol. 116, no. 2, pp. 563-606, 2001.

[87] O. Afonso and R. H. Alves, "Can the North-South trade regime explain intra and inter-country productivity differences?" Journal of International Trade and Economic Development, vol. 17, no. 4, pp. 561-595, 2008.

[88] S. Yeaple and S. Golub, "International productivity differences, infrastructure, and comparative advantage," Review of International Economics, vol. 15, no. 2, pp. 223-242, 2007.

[89] E. Leamer and J. Levinsohn, "International trade theory: the evidence," in Handbook of International Economics, Vol. III, G. Grossman and K. Rogoff, Eds., pp. 1339-1390, NorthHolland, Amsterdam, The Netherlands, 1995.

[90] W. Easterly and R. Levine, "Tropics, germs, and crops: how endowments influence economic development," NBER Working Paper 9106, 2002.

[91] D. Acemoglu, S. Johnson, and J. Robinson, "Institutions as the fundamental cause of long-run growth," in Handbook of Economic Growth, P. Aghion and S. Durlauf, Eds., vol. 1, chapter 6, pp. 385-472, 1st edition, 2005.

[92] C. Jones, "Time series tests of endogenous growth models," Quarterly Journal of Economics, vol. 110, no. 2, pp. 495-525, 1995.

[93] C. Jones, "R\&D-based models of economic growth," Journal of Political Economy, vol. 103, no. 4, pp. 759-784, 1995.

[94] D. Backus, P. Kehoe, and T. Kehoe, "In search of scale effects in trade and growth," Journal of Economic Theory, vol. 58, no. 2, pp. 377-409, 1992.

[95] E. Dinopoulos and P. Thompson, "Scale effects in Schumpeterian models of economic growth," Journal of Evolutionary Economics, vol. 9, no. 2, pp. 157-185, 1999.

[96] M. Zachariadis, "R\&D, innovation, and technological progress: a test of the Schumpeterian framework without scale effects," Canadian Journal of Economics, vol. 36, no. 3, pp. 566-586, 2003.

[97] C. Jones, "Growth: with or without scale effects?" American Economic Review, vol. 89, no. 2, pp. 139-144, 1999.

[98] P. Segerstrom, "Endogenous growth without scale effects," American Economic Review, vol. 88, no. 5, pp. 1290-1310, 1998.

[99] E. Dinopoulos and P. Segerstrom, "A Schumpeterian model of protection and relative wages," American Economic Review, vol. 89, no. 3, pp. 450-472, 1999.

[100] E. Dinopoulos and P. Segerstrom, "The dynamic effects of contingent tariffs," Journal of International Economics, vol. 47, no. 1, pp. 191-222, 1999.

[101] F. Sener, "Schumpeterian unemployment, trade and wages," Journal of International Economics, vol. 54, no. 1, pp. 119148, 2001. 
[102] E. Dinopoulos and P. Segerstrom, "North-South Trade and Economic Growth," Mimeo, Stockholm School of Economics and CEPR, 2007.

[103] O. Afonso, "Skill-biased technological knowledge without scale effects," Applied Economics, vol. 38, no. 1, pp. 13-21, 2006.

[104] G. Becker and K. Murphy, "The division of labor, coordination costs, and knowledge," Quarterly Journal of Economics, vol. 107, pp. 1137-1160, 1992.

[105] D. Quah, "Ideas determining convergence clubs," LSE, Working Paper, 1998, http://econ.lse.ac.uk/staff/dquah/p/98 06ccb.pdf.

[106] A. Alesina and E. Spolaore, "On the number and size of nations," Quarterly Journal of Economics, vol. 112, no. 4, pp. 1026-1056, 1997.

[107] E. Dinopoulos and P. Thompson, "A contribution to the empirics of endogenous growth," Eastern Economic Journal, vol. 22, pp. 389-400, 1996.

[108] N. Mankiw, D. Romer, and D. Weil, "A contribution to the empirics of economic growth," Quarterly Journal of Economics, vol. 107, pp. 407-437, 1992.

[109] P. Romer, "Human capital and growth: theory and evidence," Carnegie-Rochester Series on Public Policy, vol. 32, pp. 251286, 1990

[110] R. Barro, "Economic growth in a cross section of countries," Quarterly Journal of Economics, vol. 106, no. 2, pp. 407-443, 1991.

[111] R. Barro, "Human capital and growth in cross-country regression," Swedish Economic Review, vol. 6, pp. 237-277, 1999.

[112] R. Levine and D. Renelt, "A sensitivity analysis of crosscountry growth regressions," American Economic Review, vol. 82, no. 4, pp. 942-963, 1992.

[113] J. Benhabib and M. Spiegel, "The role of human capital in economic development: evidence from aggregate crosscountry and regional U.S. data," Journal of Monetary Economics, vol. 34, no. 2, pp. 143-174, 1994.

[114] A. Krueger and M. Lindahl, "Education for growth: why and for whom?" Journal of Economic Literature, vol. 39, no. 4, pp. 1101-1136, 2001.

[115] J. Temple, "A positive effect of human capital on growth," Economics Letters, vol. 65, no. 1, pp. 131-134, 1999.

[116] Z. Griliches, "Education, human capital, and growth: a personal perspective," Journal of Labor Economics, vol. 15, no. 1, pp. 330-344, 1997.

[117] L. Pritchett, "Where has all the education gone?" The World Bank Economic Review, vol. 15, no. 3, pp. 367-391, 2001.

[118] J. De Gregorio, "Economic growth in Latin America," Journal of Development Economics, vol. 39, no. 1, pp. 59-84, 1992.

[119] M. Knight, N. Loayza, and D. Villanueva, "Testing the neoclassical theory of economic growth: a panel data approach," IMF Staff Papers 40, 1993.

[120] N. Islam, "Growth empirics: a panel data approach," Quarterly Journal of Economics, vol. 110, pp. 1127-1170, 1995.

[121] F. Caselli, G. Esquivel, and F. Lefort, "Reopening the convergence debate: a new look at cross-country growth empirics," Journal of Economic Growth, vol. 1, no. 3, pp. 363-389, 1996.

[122] H. Engelbrecht, "International R\&D spillovers, human capital and productivity in OECD economies: an empirical investigation," European Economic Review, vol. 41, no. 8, pp. 1479-1488, 1997.

[123] A. Bartel and F. Litchtenberg, "The comparative advantage of educated workers in implementing new technologies," Review of Economics and Statistics, vol. 69, pp. 1-11, 1987.
[124] J. Mincer, Studies in Human Capital: Collected Essays of Jacob Mincer, Edward Elgar, Cambridge, UK, 1993.

[125] J. Mincer, "Investment in U.S. education and training," NBER Working Paper Series 4844, 1994.

[126] A. Bartel and N. Sicherman, "Technological change and the skill acquisition of young workers," Journal of Labor Economics, vol. 16, no. 4, pp. 718-755, 1998.

[127] G. Becker, K. Murphy, and R. Tamura, "Human capital, fertility and economic growth," Journal of Political Economy, vol. 98, pp. S12-S37, 1990.

[128] N. Stokey, "Human capital, product quality and growth," Quarterly Journal of Economics, vol. 106, pp. 587-616, 1991.

[129] M. Kiley, "The supply of skilled labour and skill-biased technological progress," Economic Journal, vol. 109, no. 458, pp. 708-724, 1999.

[130] D. Thesmar and M. Thoenig, "Creative destruction and firm organization choice," Quarterly Journal of Economics, vol. 115, no. 4, pp. 1201-1237, 2000.

[131] Ò. Afonso, "Growth and wage inequality in a scale-independent model with R\&D and human-capital accumulation," Manchester School, vol. 78, no. 2, pp. 149-182, 2010.

[132] D. Acemoglu, "Why do new technologies complement skills? Directed technical change and wage inequality," Quarterly Journal of Economics, vol. 113, no. 4, pp. 1055-1089, 1998.

[133] D. Acemoglu, "Directed technical change," Review of Economic Studies, vol. 69, no. 4, pp. 781-809, 2002.

[134] D. Acemoglu, "Technical change, inequality, and the labor market," Journal of Economic Literature, vol. 40, no. 1, pp. 772, 2002 .

[135] D. Acemoglu, "Patterns of skill premia," Review of Economic Studies, vol. 70, no. 2, pp. 199-230, 2003.

[136] J. Richardson, "Income inequality and trade: how to think, what to conclude," Journal of Economic Perspectives, vol. 9, pp. 33-56, 1995.

[137] A. Wood, "Globalisation and the rise in labour market inequalities," Economic Journal, vol. 108, no. 450, pp. $1463-$ 1482,1998

[138] L. Katz and K. Murphy, "Changes in relative wages, 1963 1987: supply and demand factors," Quarterly Journal of Economics, vol. 107, no. 1, pp. 35-78, 1992.

[139] E. Berman, J. Bound, and Z. Griliches, "Changes in the demand for skilled labor within US manufacturing industries: evidence from the annual survey of manufactures," Quarterly Journal of Economics, vol. 109, no. 2, pp. 367-398, 1994.

[140] C. Juhn, K. Murphy, and B. Pierce, "Wage inequality and the rise in returns to skill," Journal of Political Economy, vol. 101, no. 3, pp. 410-442, 1993.

[141] D. Autor, L. Katz, and A. B. Krueger, "Computing inequality: have computers changed the labor market?" Quarterly Journal of Economics, vol. 113, no. 4, pp. 1169-1213, 1998.

[142] E. Berman, J. Bound, and S. Machin, "Implications of skillbiased technological change: international evidence," Quarterly Journal of Economics, vol. 113, no. 4, pp. 1245-1279, 1998.

[143] S. Machin and J. Van Reenen, "Technology and changes in skill structure: evidence from seven OECD countries," Quarterly Journal of Economics, vol. 113, no. 4, pp. 1215-1244, 1998.

[144] S. Gera, W. Gu, and Z. Lin, "Technology and the demand for skills in Canada: an industry-level analysis," Canadian Journal of Economics, vol. 34, no. 1, pp. 132-148, 2001. 
[145] D. Acemoglu, "Changes in unemployment and wage inequality: an alternative theory and some evidence," American Economic Review, vol. 89, no. 5, pp. 1259-1278, 1999.

[146] P. Aghion, "Schumpeterian growth theory and the dynamics of income inequality," Econometrica, vol. 70, no. 3, pp. 855$882,2002$.

[147] E. Caroli and J. Van Reenen, "Skill-biased organizational change? Evidence from a panel of British and French establishments," Quarterly Journal of Economics, vol. 116, no. 4, pp. 1449-1492, 2001.

[148] A. Wood, "How trade hurts unskilled workers," Journal of Economic Perspective, vol. 9, pp. 57-80, 1995.

[149] E. Leamer, "Trade, wages and revolving-door ideas," NBER Working Paper 4716, 1994.

[150] E. Leamer, "Wage inequality from international competition and technological change: theory and country experience," American Economic Review, vol. 86, no. 2, pp. 309-314, 1996.

[151] M. Amiti and J. Konings, "Trade liberalization, intermediate inputs, and productivity: evidence from Indonesia," American Economic Review, vol. 97, no. 5, pp. 1611-1638, 2007.

[152] P. Goldberg and N. Pavcnik, "Distributional effects of globalization in developing countries," Journal of Economic Literature, vol. 45, no. 1, pp. 39-82, 2007.

[153] P. Goldberg, A. Khandelwal, N. Pavcnik, and P. Topalova, "Imported intermediate inputs and domestic product growth: evidence from India," NBER Working Paper 14416, 2008.

[154] D. Acemoglu, "Labor- and capital-augmenting technical change," Journal of the European Economic Association, vol. 1, no. 1, pp. 1-37, 2003.

[155] O. Afonso, "The impact of government intervention on wage inequality without scale effects," Economic Modelling, vol. 25, no. 2, pp. 351-362, 2008.

[156] D. A. Irwin and P. J. Klenow, "High-tech R\&D subsidies: estimating the effects of SEMATECH," Journal of International Economics, vol. 40, no. 3-4, pp. 323-344, 1996.

[157] V. Maggioni, M. Sorrentino, and M. Williams, "Mixed consequences of government aid for new venture creation: evidence from Italy," Journal of Management and Governance, vol. 3, no. 3, pp. 287-305, 1999.

[158] G. Medda, C. Piga, and D. Siegel, "Assessing the returns to collaborative research: firm-level evidence from Italy," Economics of Innovation and New Technology, vol. 15, pp. 37-50, 2006.

[159] R. Hujer and D. Radic, "Evaluating the impacts of subsidies on innovation activities in Germany," Scottish Journal of Political Economy, vol. 52, no. 4, pp. 565-586, 2005.

[160] D. Czarnitzki, P. Hanel, and J. M. Rosa, "Evaluating the impact of R\&D tax credits on innovation. A microeconometric study on Canadian firms," ZEW Discussion Paper 04-77, Mannheim, Germany, 2004.

[161] D. Czarnitzki, B. Ebersberger, and A. Fier, "The relationship between R\&D collaboration, subsidies and R\&D performance: empirical evidence from Finland and Germany," Journal of Applied Econometrics, vol. 22, no. 7, pp. 1347-1366, 2007.

[162] P. Berger, "Explicit and implicit tax effects of the R\&D tax credit," Journal of Accounting Research, vol. 31, pp. 131-171, 1993.

[163] A. Goolsbee, "Does government R\&D policy mainly benefit scientists and engineers?" American Economic Review, vol. 88, no. 2, pp. 298-302, 1998.
[164] G. Cozzi and G. Impullitti, "Technology policy and wage inequality," 2006, http://www.gla.ac.uk/media/media_89750 _en.pdf.

[165] E. Lai, "International intellectual property rights protection and the rate of product innovation," Journal of Development Economics, vol. 55, no. 1, pp. 133-153, 1998.

[166] E. Lai and L. Qiu, "The North's intellectual property rights standard for the South?" Journal of International Economics, vol. 59, no. 1, pp. 183-209, 2003.

[167] A. Glass and K. Saggi, "Intellectual property rights and foreign direct investment," Journal of International Economics, vol. 56, no. 2, pp. 387-410, 2002.

[168] P. Smith, "How do foreign patent rights affect U.S. exports, affiliate sales, and licenses?" Journal of International Economics, vol. 55, no. 2, pp. 411-439, 2001.

[169] K. Maskus, "Encouraging Technology Transfer," Report for UNCTAD/ICTSD Project on Intellectual Property Rights and Sustainable Development 7, 2004.

[170] L. Branstetter, R. Fisman, and C. Foley, "Do stronger intellectual property rights increase technology transfer? Empirical evidence from U. S. firm-level panel data," Quarterly Journal of Economics, vol. 121, no. 1, pp. 321-349, 2005.

[171] G. Yang and K. Maskus, "Intellectual property rights, licensing, and innovation in an endogenous product-cycle model," Journal of International Economics, vol. 53, no. 1, pp. 169187, 2001. 


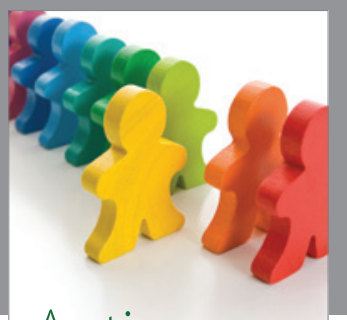

Autism

Research and Treatment
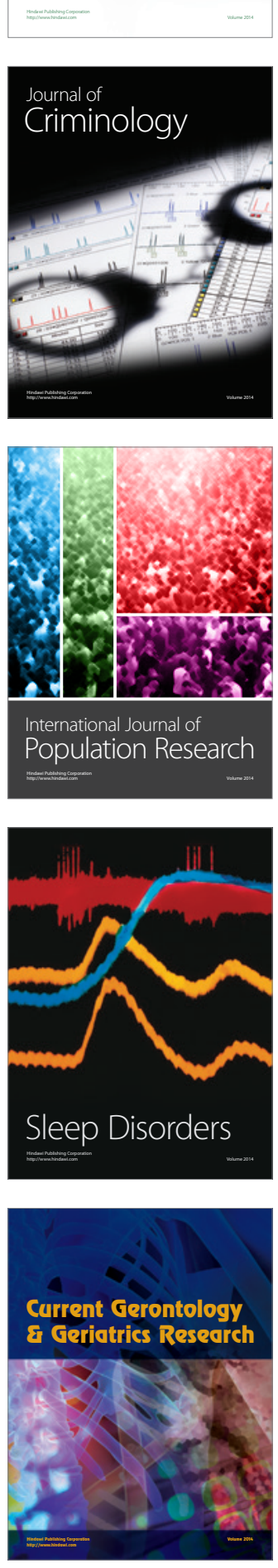
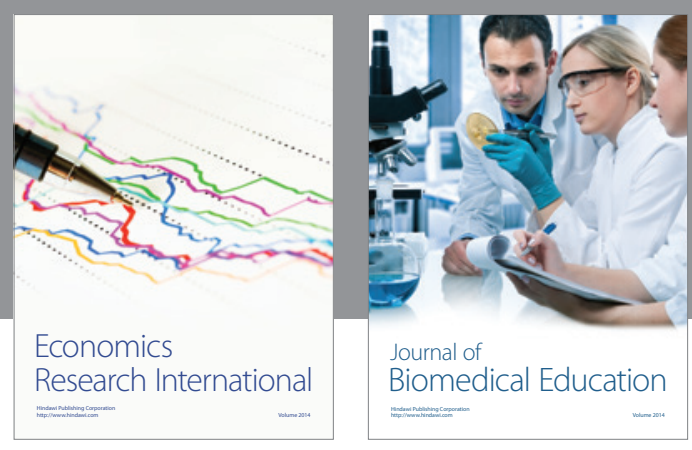

Journal of

Biomedical Education

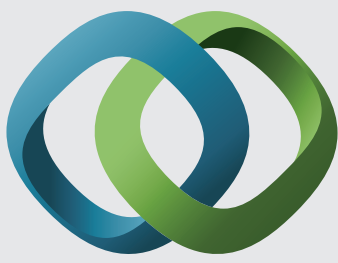

\section{Hindawi}

Submit your manuscripts at

http://www.hindawi.com
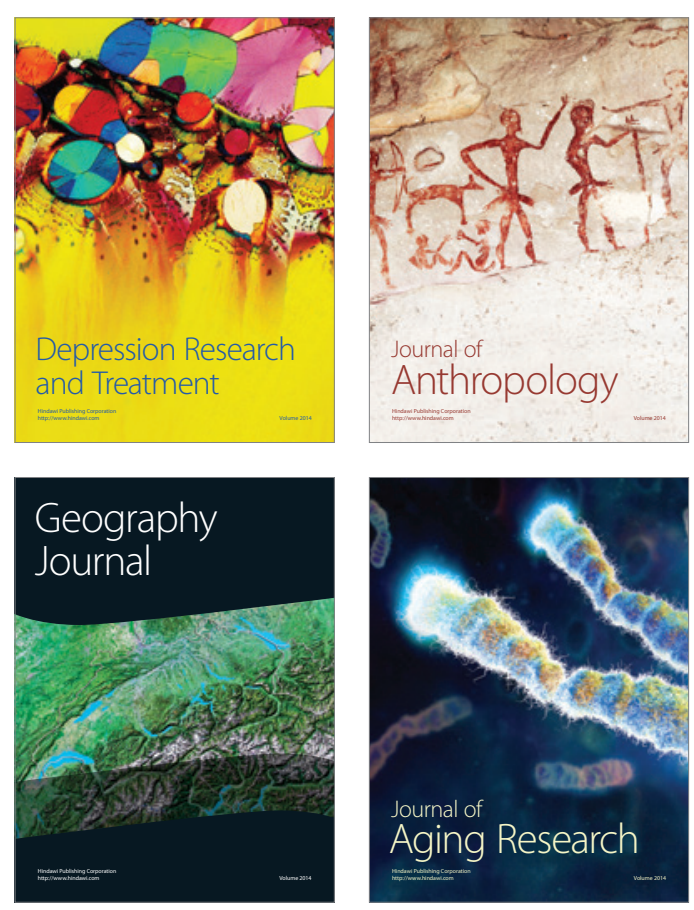

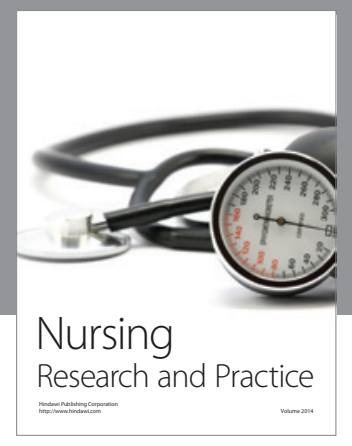

Nursing

Research and Practice

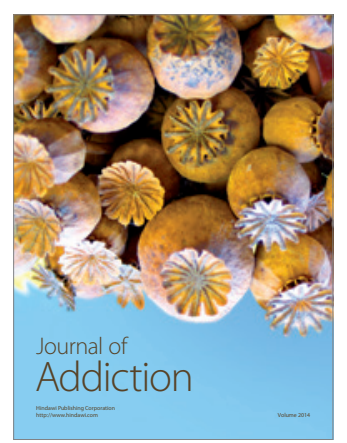

Child Development

Research

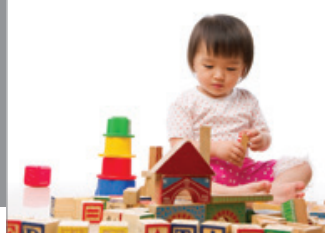

迥
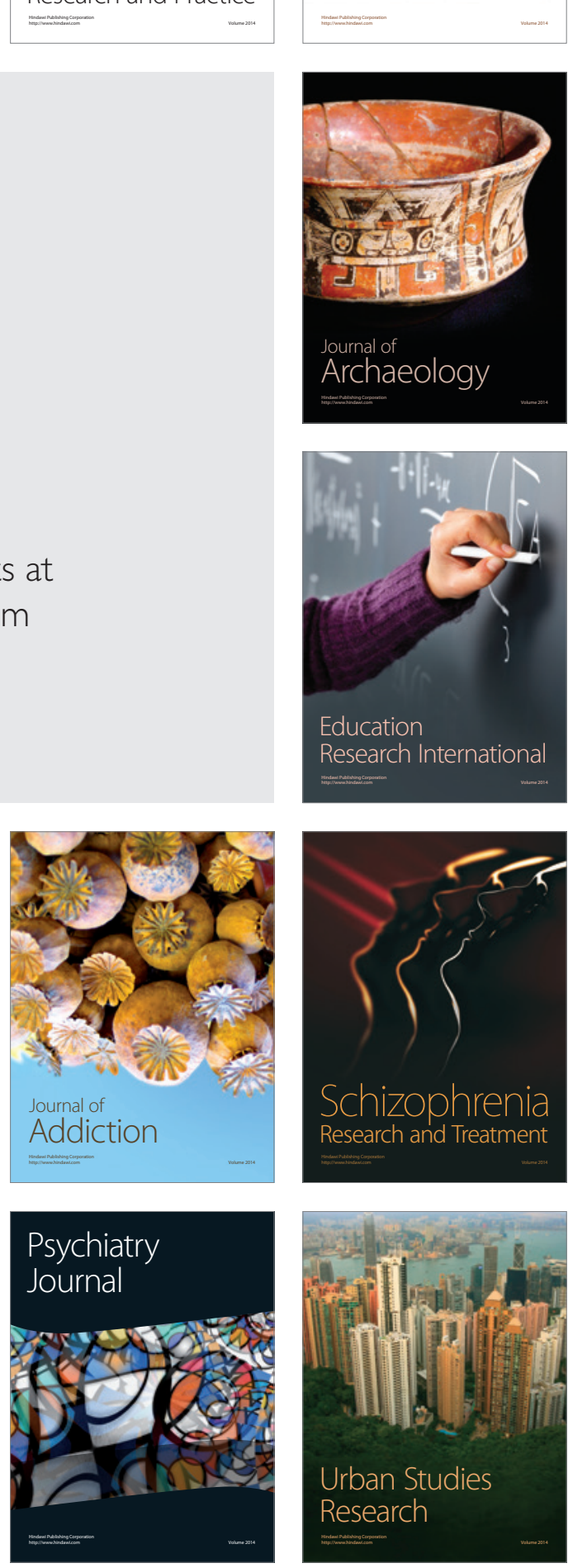